Ann. For. Sci. 56 (1999) 179-187

(C) Inra/Elsevier, Paris

Original article

\title{
Response of Pinus pinaster Ait. provenances at early age to water supply. I. Water relation parameters
}

\author{
Manuel Fernández, Luis Gil, José A. Pardos* \\ Unidad de Anatomía, Fisiología y Genética, ETS de Ingenieros de Montes, Ciudad Universitaria s/n, \\ Universidad Politécnica de Madrid, 28040 Madrid, Spain
}

(Received 8 December 1997; revised 11 March 1998; accepted 17 August 1998)

\begin{abstract}
The seasonal evolution of tissue water relations was assessed in 1-year-old seedlings of four Pinus pinaster Ait. provenances growing in a nursery and subjected to two water supply regimes. Seedlings were also submitted to water stress cycles in a controlled environment chamber. Water relation parameters were deduced from pressure-volume curves. Significant differences were found between water supply regimes and measurement dates and sometimes among provenances. For the lowest water availability treatment, osmotic potential at full turgor decreased by $0.4 \mathrm{MPa}$ in some provenances, whereas well-watered seedlings showed almost no osmotic adjustment. Provenances originating from hotter sites demonstrated a larger and more rapid acclimation to water stress conditions than provenances from colder sites. Osmotic adjustment, as an initial or short-term reaction, together with longerterm changes in cellular elasticity, are both observed in $P$. pinaster in response to water shortage. These physiological adaptations complement known morphological adaptations to drought stress in this species. With caution, assessment of these parameters in young seedlings can be used as a tool for early selection and prediction of future performance under conditions of water limitations. (ㅇ) Inra/Elsevier, Paris.)
\end{abstract}

maritime pine / early selection / water relation parameter

Résumé - Réponse au stress hydrique des provenances de Pinus pinaster Ait. à un âge précoce. I. Paramètres hydriques. L'évolution saisonnière des relations hydriques a été déterminée chez quatre provenances de semis d'un an de Pinus pinaster Ait, installées en pépinière et soumises à deux régimes d'arrosage. Des semis étaient aussi soumis à des cycles de stress hydrique dans une chambre climatisée. Les paramètres des relations hydriques ont été déduits de courbes pression-volume. Des différences significatives ont été trouvées entre les différents types d'arrosage et aussi entre dates de mesure et provenances. En ce qui concerne le traitement correspondant au stress hydrique le plus important, on a constaté que le potentiel osmotique à pleine turgescence diminuait de 0,4 MPa chez certaines provenances alors qu'il n'y avait pratiquement pas d'ajustement osmotique chez les semis bien arrosés. Les provenances originaires des stations les plus chaudes ont montré une acclimatation plus grande et plus rapide aux conditions de sécheresse que les provenances des stations plus froides. En réponse à la sécheresse il a été observé chez Pinus pinaster un ajustement osmotique, réaction à court terme, avec un changement à long terme de l'élasticité cellulaire. Ces adaptations physiologiques complètent des connaissances déjà acquises sur les adaptations morphologiques à la sécheresse chez ces espèces. Avec précaution, la détermination de ces paramètres chez de jeunes semis peut être utilisée comme un outil pour une sélection précoce et la prédiction des performances futures en situation de limitation en eau. (C Inra/Elsevier, Paris.)

pin maritime / sélection précoce / paramètres de relation hydrique

\footnotetext{
* Correspondence and reprints

jpardos@montes.upm.es
} 


\section{INTRODUCTION}

Pinus pinaster is widely distributed in the Mediterranean basin. Natural populations as well as plantations occupy more than 1.4 million ha in Spain. New plantations are being established in the Iberian Peninsula and more are planned for the near future [10]. However, water supply affects survival and growth in some plantations especially if appropriate provenances are not used. Limited research has shown the presence of some differences in response to water stress between provenances [18, 37]. Nguyen and Lamant [30] observed differences in osmotic adjustment between provenances; however, more research is needed [26].

The historic necessity to complete a breeding cycle in order to select and propagate high yielding trees may be shortened through early selection [11]. This not only reduces the waiting time but allows the selection intensity to be increased and even leads to a higher heritability because of the lower environmental variation [19]. In fact, for many species early selection revealed the existence of genetic differences in growth rate and the occurrence, in some genotypes, of a better adaptation and a higher yield under water stress conditions [8]. A common experimental approach consists of submitting plants to a range of water supply regimes, and to evaluate morphological, physiological and genetic parameters in order to establish a ranking regarding the taxons (species, provenances, genotypes) under study [23].

Exposure to drought induces some acclimation; however, plants need to detect small decreases in soil moisture content and react quickly to avoid harmful dehydration [33]. This response is likely under moderate genetic control [29].

The parameters deduced from pressure-volume curves (osmotic potential at full turgor and at turgor loss, relative water content at turgor loss, bulk elasticity modulus, apoplastic water) provide some information on a plant's capacity (such as osmoregulation, cellular elasticity, cel- lular water relations) to maintain growth and to avoid damage due to water stress [6].

The present work analyses the responses of several ecologically distant provenances of $P$. pinaster to water availability in terms of tissue water relation parameters. Seedlings are subjected to a range of water supply regimes under nursery and growth chamber conditions, in order to establish criteria for early selection and suitability for afforestation on droughty sites.

\section{MATERIALS AND METHODS}

During April 1994, seeds from the three Iberian provenances (Oria [Or], Arenas de San Pedro [Ar] and San Leonardo de Yagüe [SL]) and two open pollinated families of one French provenance (Landes [Ld]) were collected (figure 1, table I) and germinated on moist perlite at $20^{\circ} \mathrm{C}$ and $14 \mathrm{~h}$ photoperiod. After germination, seedlings were taken to open air under translucid cover and sown in containers filled with $230 \mathrm{~mL}$ of sand:black peat mixture $(2: 1 \mathrm{v} / \mathrm{v})$. A weather station recorded air temperatures (figure 2).

All seedlings were watered twice a week for 2 months. A fungicide (Captan $0.1 \%$ ) was systematically sprayed on the plants. After 2 months, two different water supply regimes were applied: once a week (R1) and every 2 nd week (R2) to field capacity. The experimental design consisted of 12 completely randomised blocks with 15 plants per block, provenance and water supply regime - altogether 1440 seedlings.

Three times (June, 2nd week; July, 3rd week; and September, 2nd week), four plants per provenance and water supply regime were removed just before watering and used for the pressure-volume analysis. Water potential was measured using a pressure chamber (PMS Instruments Co. Corvallis, OR, USA) according to Ritchie and Hinckley [34]. Pressure-volume curves were constructed following the technique of Koide et al. [22]. In brief, the construction of pressure-volume curves was

Table I. Ecological characteristics of Pinus pinaster provenance regions.

\begin{tabular}{lcccccccc}
\hline & $\begin{array}{c}\text { Area } \\
(\mathrm{ha})\end{array}$ & $\begin{array}{c}\text { Altitude } \\
(\mathrm{m})\end{array}$ & $\begin{array}{c}\mathrm{T} \\
\left({ }^{\circ} \mathrm{C}\right)\end{array}$ & $\begin{array}{c}\mathrm{P} \\
(\mathrm{mm})\end{array}$ & Latitude & Longitude & $\begin{array}{c}\text { DBI } \\
(\mathrm{bcu} / \mathrm{m})\end{array}$ & Phytoclimate \\
\hline $\mathrm{Or}$ & 1632 & 1150 & 15.8 & 357 & $37^{\circ} 30^{\prime} \mathrm{N}$ & $2^{\circ} 20^{\prime} \mathrm{W}$ & -1.00 & $\mathrm{IV}_{1}$ \\
$\mathrm{Ar}$ & 34760 & 750 & 13.4 & 1190 & $40^{\circ} 07^{\prime} \mathrm{N}$ & $4^{\circ} 17^{\prime} \mathrm{W}$ & -1.38 & $\mathrm{VI}^{\prime}(\mathrm{IV})_{2} / \mathrm{IV}_{4}$ \\
$\mathrm{SL}$ & 21464 & 1200 & 8.7 & 641 & $41^{\circ} 43^{\prime} \mathrm{N}$ & $2^{\circ} 27^{\prime} \mathrm{W}$ & -0.08 & $\mathrm{VI}(\mathrm{IV})_{1} / \mathrm{VI}(\mathrm{IV})_{2}$ \\
$\mathrm{Ld}$ & 1000000 & 40 & 12.0 & 833 & $44^{\circ} 00^{\prime} \mathrm{N}$ & $1^{\circ} 00^{\prime} \mathrm{W}$ & 0.00 & $\mathrm{VI}(\mathrm{V})$ \\
\hline
\end{tabular}

T: annual mean temperature; P: annual mean precipitation; Phytoclimate [3]; DBI: dry bioclimatic intensity [28]. 


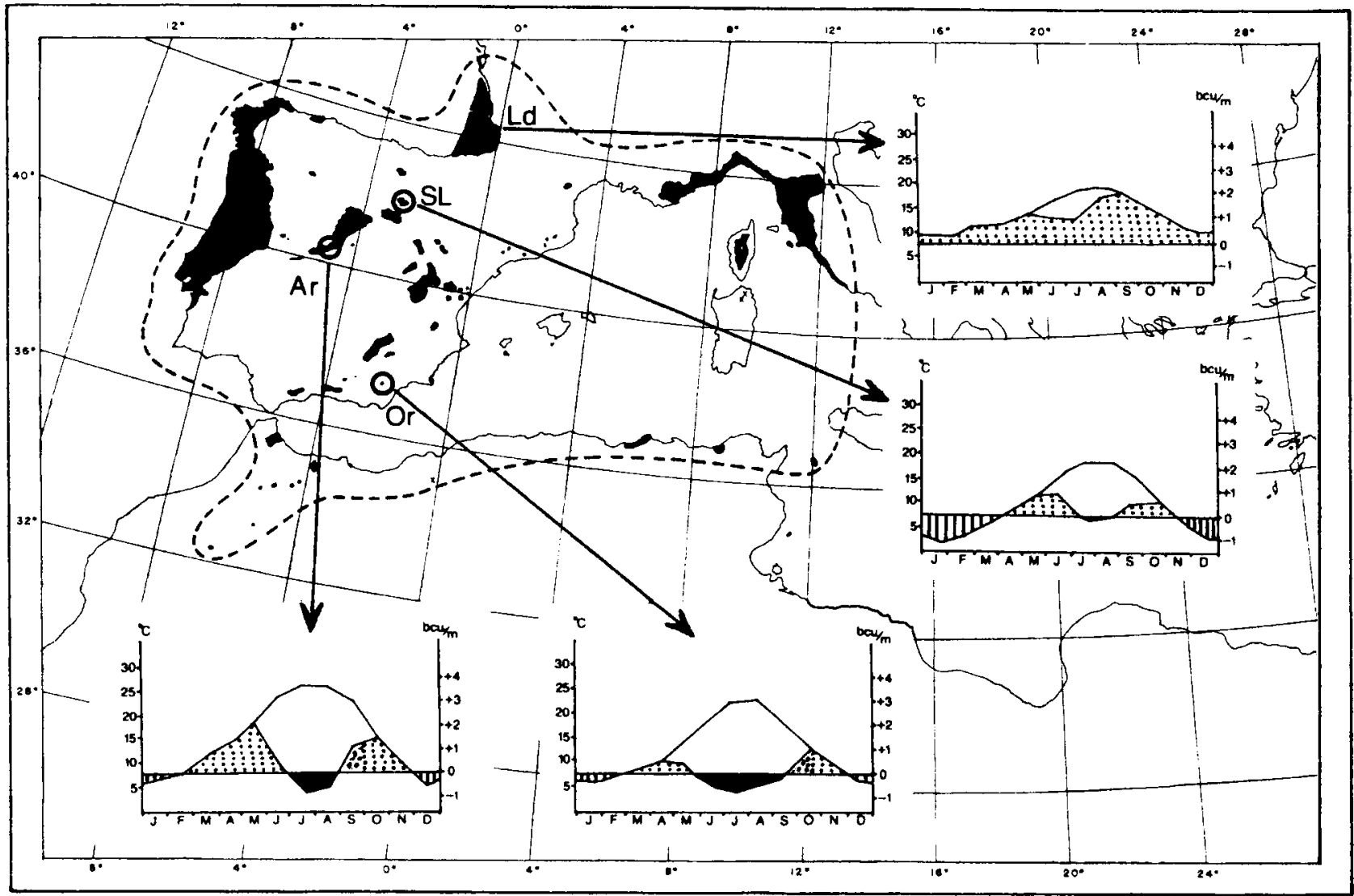

Figure 1. Natural range of Pinus pinaster, location of the provenances (Oria [Or], Arenas de San Pedro [Ar], San Leonrado de Yagüe [SL], Landes [Ld]) and bioclimatic diagrams according to [28]. Bioclimatic intensities: $o$ free $=$ favourable growing conditions for plants, $\mathbf{d r y}=$ summer dormancy and $\mathbb{1}$. cold = winter dormancy.

as follows: Five-cm long shoot segments from the apex of the plants were removed, their basal ends were placed into distilled water and were allowed to rehydrated for $12 \mathrm{~h}$ in closed tubes in a cool dark humid chamber. As a result, a water potential value between -0.02 to -0.05 $\mathrm{MPa}$ was achieved. At this point, the shoot segments were allowed to dry under ambient conditions in the laboratory (at a nearly constant temperature of $20^{\circ} \mathrm{C}$ ). Then, at intervals, fresh weight and water potential were measured. Curves with oversaturation points were less than 5 $\%$ of the samples; in these cases the points in the plateau region were omitted and the curves were corrected according to Kubiske and Abrams [24]. The following parameters were then calculated: osmotic potential at full turgor $(\Psi \pi 100)$ and at turgor loss $(\Psi \pi 0)$ and the osmotic amplitude for turgor maintenance $(\Delta \Psi \pi=\Psi \pi 100-$ $\Psi \pi 0$ ), relative water content at turgor loss (RWC0),

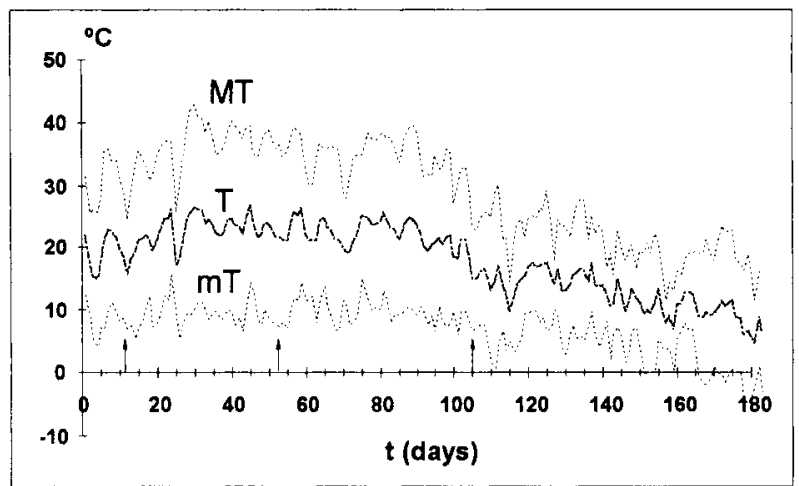

Figure 2. Maximum (MT), minimum (mT) and mean (T) daily temperatures $\left({ }^{\circ} \mathrm{C}\right.$ ) throughout the experiment ( 1 June to 30 November 1994). Arrows indicate the days of measurements. 
apoplastic water at full turgor to dry weight ratio (Wap/DW), maximum elasticity modulus (Emax) and weight at full turgor to dry weight ratio (TW/DW).

At the same time, height $(\mathrm{H})$, dry weight (DW) after $48 \mathrm{~h}$ at $70^{\circ} \mathrm{C}$, projected needle area (PNA), specific leaf area (SLA, $\mathrm{m}^{2}{ }_{\text {needles }} / \mathrm{g}_{\text {ncedles }}$ ), predawn and midday water potentials $(\Psi \mathrm{pd}, \Psi n)$ and gas exchange parameters (net photosynthetic and transpiration rates $[\mathrm{A}, \mathrm{E}]$ and stomatal conductance to water vapour [gw]) were recorded, immediately before the next irrigation, on ten plants per provenance and water supply regime. Projected needle area was measured with a leaf area meter (Delta $\mathrm{T}$ Devices Cambridge, UK). A, E and gw were measured with a portable infrared gas analyser (LCA-4, ADC, Hoddesdon, England) between 1200 and 1400 hours, and expressed and analysed on a projected needle surface basis.

On 1 May 1995, 18 seedlings of each Iberian provenance were taken to a growth chamber and watered twice a week until 16 June. Chamber conditions were $22{ }^{\circ} \mathrm{C}$, $65 \%$ relative humidity $(\mathrm{RH})$ and $200 \mu \mathrm{mol} \cdot \mathrm{m}^{-2} \cdot \mathrm{s}^{-1}$ maximum photosynthetic active radiation (PAR) during the light period $(14 \mathrm{~h})$ and $17{ }^{\circ} \mathrm{C}, 75 \% \mathrm{RH}$ in the dark. Plants were submitted to consecutive cycles of drought, each cycle ending as soon as predawn water potential was between -1.2 and $-1.5 \mathrm{MPa}$. The plants were then watered again to field capacity and a new cycle was begun. Three times (19 June, 21 July and 7 September) four plants per treatment were again removed and pressure-volume curves were constructed.
Variance analysis using a BMDP2V statistic package (BMOP Statistical Software Inc., Cork, Ireland) was applied to the data in order to discriminate among provenances, watering treatments, measurement dates and blocks. The Tukey HSD (Honest Significant Difference) for means comparison was applied whenever differences were significant $(P<0.05)$.

\section{RESULTS}

\subsection{Plants at the nursery}

The block effect was not statistically significant for any water relation or gas exchange parameter $(P>0.20)$, so this was excluded from the statistical analysis presented henceforth.

Tables $I I$ and $I I I$ illustrate the mean values of water potential and other morphological and gas exchange parameters. Water potential and gas exchange rate values were not significantly different among provenances; however, provenances showed differences in growth and SLA. Arenas, Oria and Landas provenances stand out because of their growth for the R1 treatment. For R2, the Landas families lost the potential of biomass production they showed under high water availability. Survival rate was higher than $97 \%$ for all provenances for the R1 treatment and in the range of $67-80 \%$, according to provenance, for the $\mathrm{R} 2$ treatment; the largest mortality

Table II. Mean value for each provenance (Or, Ar, SL, Ld) and water supply regime (R1, R2). Height increment $\left(\Delta H=H_{\text {september }}-\right.$ $\left.\mathrm{H}_{\text {june }}, \mathrm{mm}\right)$, dry weight increment $\left(\Delta \mathrm{DW}=\mathrm{DW}_{\text {septemher }}-\mathrm{DW}_{\text {june }}, \mathrm{g}\right)$, projected needle area increment $\left(\Delta \mathrm{PNA}=\mathrm{PNA}_{\text {september }}-\right.$ $\mathrm{PNA}_{\text {june }}, \mathrm{cm}^{2}$ ) and mean specific leaf area (SLA, $\mathrm{m}^{2}$ needles $/ \mathrm{g}_{\text {necdles }}$ ) from June to September. Means with the same letter do not differ significantly (Tukey's HSD test, $P=0.05$ ).

\begin{tabular}{|c|c|c|c|c|}
\hline & $\Delta \mathrm{H}$ & $\Delta \mathrm{DW}$ & $\triangle \mathrm{PNA}$ & SLA \\
\hline \multicolumn{5}{|l|}{ Provenance } \\
\hline Or & $57.1 \mathrm{a}$ & $0.327 \mathrm{~b}$ & $10.9 \mathrm{ab}$ & $7.56 \mathrm{a}$ \\
\hline $\mathrm{Ar}$ & $78.2 b$ & $0.352 \mathrm{~b}$ & $11.7 \mathrm{~b}$ & $8.05 \mathrm{a}$ \\
\hline $\mathrm{SL}$ & $58.0 \mathrm{a}$ & $0.236 \mathrm{a}$ & $8.6 \mathrm{a}$ & $8.81 \mathrm{~b}$ \\
\hline $\mathrm{Ld}$ & $81.5 \mathrm{c}$ & $0.331 \mathrm{~b}$ & $11.7 \mathrm{~b}$ & $9.23 \mathrm{~b}$ \\
\hline \multicolumn{5}{|l|}{ Water treatment } \\
\hline Rl & 79.8 & 0.362 & 13.2 & 8.65 \\
\hline $\mathrm{R} 2$ & 57.7 & 0.262 & 8.3 & 8.18 \\
\hline \multicolumn{5}{|l|}{$P$ value } \\
\hline Provenance $(\mathrm{P})$ & $* * *$ & $* * *$ & $* * *$ & $* * *$ \\
\hline Water treatment (WT) & $* * *$ & $* * *$ & $* * *$ & $* *$ \\
\hline $\mathrm{P} \times \mathrm{WT}$ & $* *$ & $*$ & $*$ & n.s. \\
\hline
\end{tabular}


Table III. Mean value \pm standard error of predawn water potential ( $\Psi$ pd, MPa), midday water potential $(\Psi n, \mathrm{MPa})$, net photosynthetic rate $\left(\mathrm{A}, \mu \mathrm{molCO}_{2} \cdot \mathrm{m}-2 \cdot \mathrm{s}^{-1}\right)$, net transpiration rate $\left(\mathrm{E}, \mathrm{mmolH}_{2} \mathrm{O} \cdot \mathrm{m}^{-2} \cdot \mathrm{s}^{-1}\right)$ and stomatal conductance $\left(\mathrm{mmolH}_{2} \mathrm{O} \cdot \mathrm{m}^{-2} \cdot \mathrm{s}^{-1}\right)$.

\begin{tabular}{|c|c|c|c|c|c|c|}
\hline Water treatment & Date & $\Psi_{\mathrm{pd}}$ & $\Psi_{n}$ & A & $\mathrm{E}$ & gw \\
\hline \multirow{3}{*}{$\mathrm{R} 1$} & June & $-0.54 \pm 0.01$ & $-0.89 \pm 0.01$ & $9.2 \pm 0.4$ & $2.2 \pm 0.1$ & $100 \pm 6$ \\
\hline & July & $-0.49 \pm 0.01$ & $-1.05 \pm 0.02$ & $6.3 \pm 0.3$ & $2.0 \pm 0.1$ & $68 \pm 5$ \\
\hline & September & $-0.62 \pm 0.02$ & $-1.05 \pm 0.01$ & $10.1 \pm 0.4$ & $2.8 \pm 0.1$ & $144 \pm 8$ \\
\hline $\mathrm{R} 2$ & June & $-0.65 \pm 0.01$ & $-0.99 \pm 0.01$ & $3.2 \pm 0.4$ & $1.3 \pm 0.1$ & $28 \pm 3$ \\
\hline
\end{tabular}

Differences between water supply treatments and dates were significantly different for these five parameters $(P<0.001)$.

Table IV. Mean value \pm standard error of parameters deduced from pressure-volume curves for provenances altogether and for every water supply regime and measurement date. Osmotic potential at full turgor $(\Psi \pi 100, \mathrm{MPa})$, osmotic potential at turgor loss $(\Psi \pi 0$, $\mathrm{MPa}$ ), relative water content at turgor loss ( $\mathrm{RWC0}, \%)$, maximum elasticity modulus ( $\varepsilon$ max, MPa), full turgor weight to dry weight ratio (TW/DW) and apoplastic water to dry weight ratio (Wap/DW).

\begin{tabular}{|c|c|c|c|c|c|c|}
\hline & $\Psi \pi 100$ & $\Psi \pi 0$ & RWC0 & $\varepsilon \max$ & TW/DW & Wap/DW \\
\hline \multicolumn{7}{|l|}{ Provenance } \\
\hline $\mathrm{Or}$ & $-1.37 b$ & $-1.91 b$ & $81.3 \mathrm{a}$ & $5.71 b$ & $3.69 \mathrm{a}$ & $1.05 \mathrm{a}$ \\
\hline $\mathrm{Ar}$ & $-1.24 \mathrm{a}$ & $-1.76 \mathrm{a}$ & $84.9 \mathrm{~b}$ & $5.08 \mathrm{ab}$ & $4.11 \mathrm{a}$ & $1.34 \mathrm{~b}$ \\
\hline SL & $-1.14 \mathrm{a}$ & $-1.71 \mathrm{a}$ & $83.9 \mathrm{~b}$ & $4.35 \mathrm{a}$ & $4.35 \mathrm{ab}$ & $1.64 \mathrm{c}$ \\
\hline Ld & $-1.18 \mathrm{a}$ & $-1.73 \mathrm{a}$ & $83.9 \mathrm{~b}$ & $6.31 \mathrm{~b}$ & $4.47 b$ & $1.51 \mathrm{bc}$ \\
\hline $\mathrm{R} 1$ & -1.19 & -1.60 & 83.8 & 6.23 & 4.49 & 1.38 \\
\hline $\mathrm{R} 2$ & -1.27 & -1.95 & 83.2 & 4.49 & 3.82 & 1.39 \\
\hline \multicolumn{7}{|l|}{ Date } \\
\hline June & $-1.17 \mathrm{a}$ & $-1.60 \mathrm{a}$ & $84.0 \mathrm{a}$ & $6.21 \mathrm{~b}$ & $4.44 \mathrm{~b}$ & $1.53 \mathrm{~b}$ \\
\hline July & $-1.26 b$ & $-1.94 c$ & $83.4 \mathrm{a}$ & $4.48 \mathrm{a}$ & $3.92 \mathrm{a}$ & $1.51 \mathrm{~b}$ \\
\hline
\end{tabular}

Table V. Significance level $(P)$ for every parameter according to variance analysis.

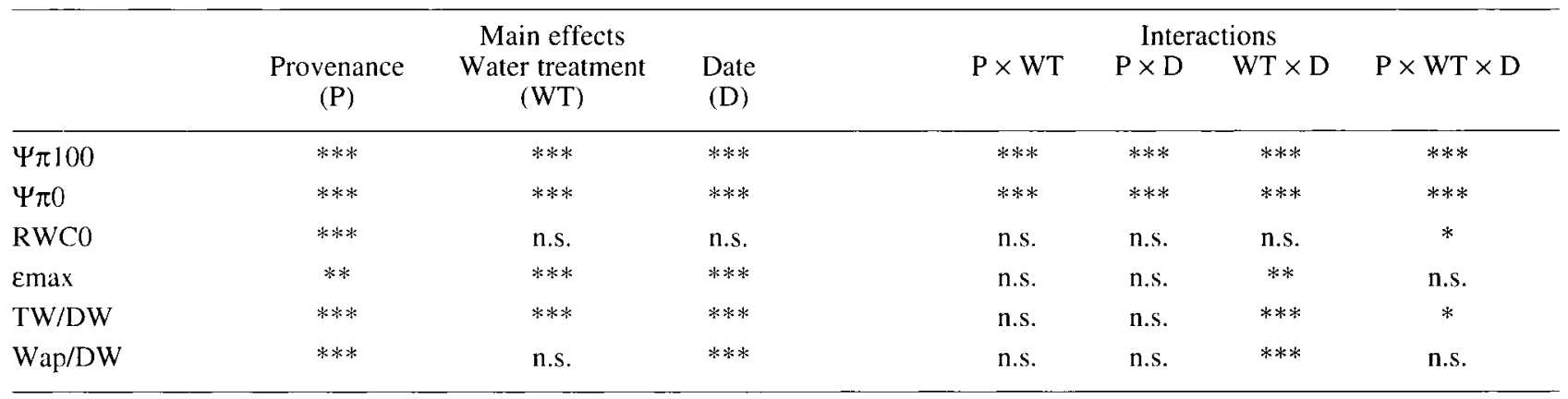

n.s.: not significant $(P>0.05) ; *: P \leq 0.05 ; * * P \leq 0.01 ; * * * P \leq 0.001$. 
(16\%) occurred during July, the period of highest water stress.

Table IV shows the mean values for the majority of water relation parameters, and table $V$ presents the levels of significance, taking into account the effect of provenance, water supply treatment, measurement date and their interaction. The differences between provenances or between dates with regard to water relation parameters derived from pressure-volume curves were greater for the R2 than for the R1 treatment, with the exception of RWC 0 . The Landes provenance showed the highest tissue water content ratio (TW/DW), the water accumulation was greatest in the symplast. For the $\mathrm{R} 2$ treatment, there were only small differences between provenances during June and September for $\Psi \pi 100$; however, during July $\Psi \pi 100$ (figure 3) was significantly lower in the Oria and Arenas provenances $(\mathrm{Or}=-1.70 \pm 0.07 ; \mathrm{Ar}=-1.52$ $\pm 0.07 ; \mathrm{SL}=-1.13 \pm 0.06$ and $\mathrm{Ld}=-1.18 \pm 0.07 \mathrm{MPa}$ ). Similar results were noted for $\Psi \pi 0$. The exposure to water stress in June led later in July to decreases in $\Psi \pi 100, \Psi \pi 0, \varepsilon \max$ and TW/DW ratio, whereas $\Delta \Psi \pi$ increased. From July to September the previously mentioned water relation parameters changed but in the opposite direction from that noted from June to July. Nevertheless, for most of the parameters the initial June values were not reached by September. For all the provenances, the decrease in TW/DW value from June to September was not due to a concomitant drop in Wap/DW (table IV); therefore, it was likely due to a decrease of symplastic water content.

\subsection{Growth chamber experiment}

Table VI shows the measured water relation parameters and their significance level based upon analysis of

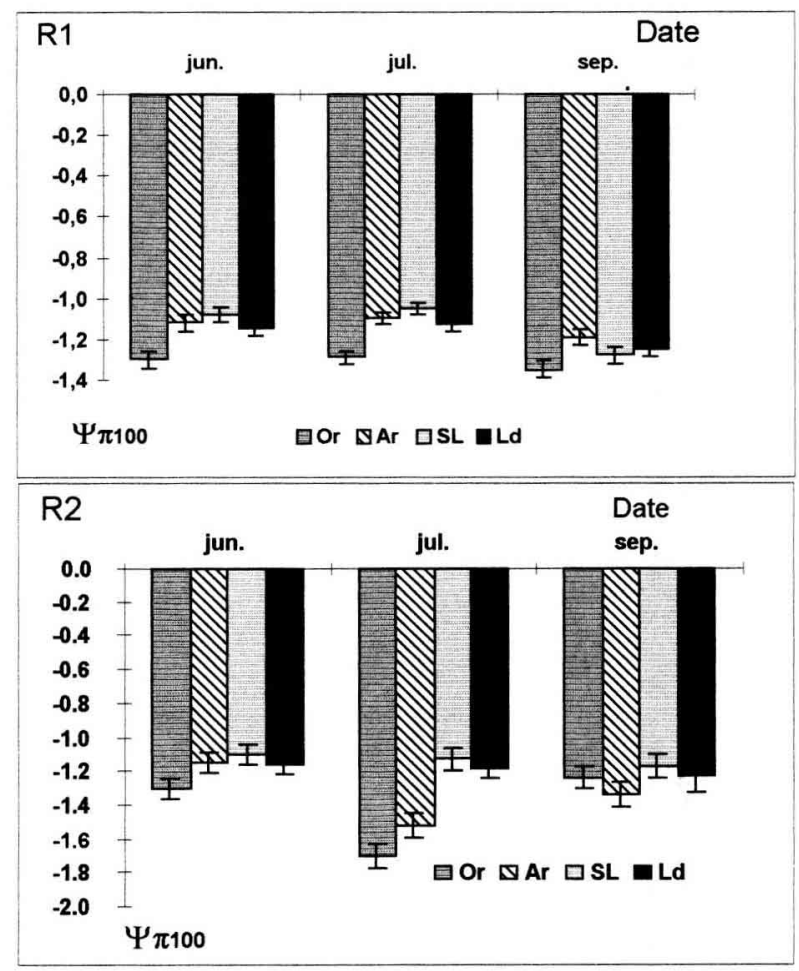

Figure 3. Osmotic potential at full turgor ( $\Psi \pi 100, \mathrm{MPa})$ for each provenance, measurement date and water supply regime.

variance (ANOVA). Differences between provenances were not significant for any parameter $(0.122<$ $P<0.888$ ), neither was the interaction of provenance $\times$ date $(0.124<P<0.917)$. Only date was observed to have a significant effect $(P \leq 0.040)$.

Table VI. Mean value \pm standard error and significance level $(P)$ of every parameter for the plants of the growth chamber. Osmotic potential at full turgor $(\Psi \pi 100, \mathrm{MPa})$, osmotic potential at turgor loss $(\Psi \pi 0, \mathrm{MPa})$, relative water content at turgor loss $(\mathrm{RWC} 0, \%)$, maximum elasticity modulus ( $\varepsilon$ max, MPa), full turgor weight to dry weight ratio (TW/DW) and apoplastic water to dry weight ratio (Wap/DW).

\begin{tabular}{lcccccc}
\hline & Day 0 & $\begin{array}{c}\text { Date } \\
\text { Day } 32\end{array}$ & Day 80 & Provenance (P) & $\begin{array}{c}P \text { value } \\
\text { Date (D) }\end{array}$ & $\mathrm{P} \times \mathrm{D}$ \\
\hline$\Psi \pi 100$ & $-1.39 \pm 0.04$ & $-1.59 \pm 0.02$ & $-1.72 \pm 0.05$ & $\mathrm{n} . \mathrm{s}$ & $* * *$ & $n . \mathrm{s}$ \\
$\Psi \pi 0$ & $-2.00 \pm 0.05$ & $-2.33 \pm 0.03$ & $-2.47 \pm 0.06$ & $\mathrm{n} . \mathrm{s}$ & $* * *$ & $n . \mathrm{s}$ \\
RWC0 & $82.2 \pm 0.9$ & $81.5 \pm 0.5$ & $-78.2 \pm 0.9$ & $\mathrm{n} . \mathrm{s}$ & $* *$ & $n . \mathrm{s}$ \\
$\varepsilon \max$ & $5.41 \pm 0.56$ & $5.96 \pm 0.30$ & $7.52 \pm 0.49$ & $n . \mathrm{s}$ & $* *$ & $n . \mathrm{s}$ \\
TW/DW & $3.5 \pm 0.1$ & $3.4 \pm 0.1$ & $3.7 \pm 0.2$ & $n . \mathrm{s}$ & $*$ & $n . \mathrm{s}$ \\
Wap/DW & $1.0 \pm 0.1$ & $0.95 \pm 0.0$ & $0.72 \pm 0.1$ & $n . \mathrm{s}$ & $*$ & $n . \mathrm{s}$ \\
\hline
\end{tabular}

n.s.: no significant $(P>0.05) ; * P \leq 0.05 ; * *: P \leq 0.01 ; * * *: P \leq 0.001$. 


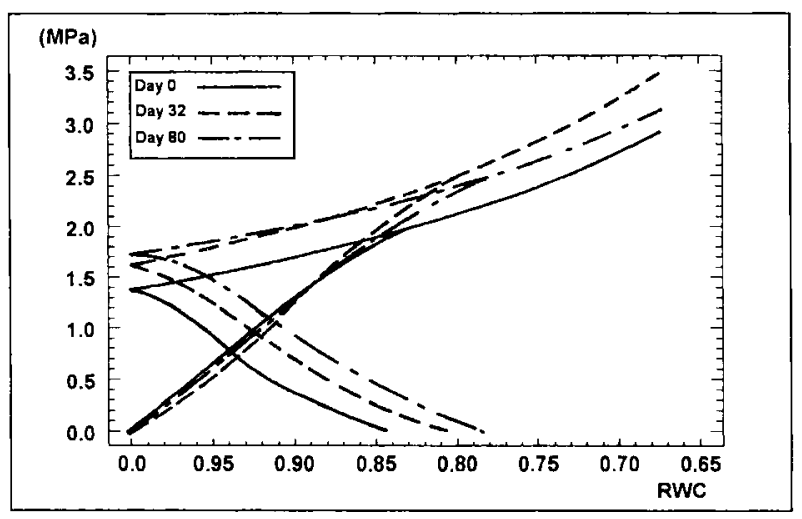

Figure 4. Höfler diagram for seedlings grown in the climatic chamber (San Leonardo provenance).

The first response to water stress cycles (from day 1 to 32) was a significant decrease of $\Psi \pi 100$ and $\Psi \pi 0$ and an increase of $\Delta \Psi \pi$. Changes in RWC $0, \varepsilon \max$, TW/DW and Wap/DW were not significant until the third measurement (day 80), then an increase of TW/DW and a decrease of Wap/DW were observed. Figure 4 illustrates a Höfler diagram for one of the three provenances (SL). Diagrams for the other provenances were quite similar.

\section{DISCUSSION}

In general, water potential and gas exchange values from this study were similar to those from other studies of pine species $[7,15]$. For the RI treatment, mean values were not significantly different among provenances. Predawn water potential dropped to $-0.5 \mathrm{MPa}$ after 7 days without water. Although Tschaplinski et al. [39] observed that such predawn values can affect plants, $P$. pinaster showed no effect and continued to grow. In addition, values of noon or minimum water potential indicated no stress. Under water shortage conditions (R2), water stress was high and predawn water potential approached the survival threshold. Differences among provenances were not significant. Stomata closed, as is made evident by the values recorded for gas exchange parameters, and growth was restricted. The restriction of growth due to lack of available water is a well-known general response of plants [5]; such observations have been made in 1-year-old P. pinaster [16]. For comparison, threshold values of water potential that result in stomata closure and a decrease in photosynthesis of some Pinaceae species are listed: $-1.3 \mathrm{MPa}$ for Pinus pinaster [9], -1.2 MPa for Cedrus atlantica, -1.5 MPa for Pseuotsuga menziesii (Mirb.) Franco,-1.9 MPa for
Pseudotsuga macrocarpa [12], -1.5 MPa for Larix occidentalis Nutt. [17], -1.75 MPa for Pinus banksiana Lamb. and Picea glauca (Moench) Voss. [15].

For the $\mathrm{R} 1$ treatment, differences between provenances are small with regard to water relation parameters derived from pressure-volume curves. Pressure potential was always positive $(\Psi P>0)$, since water potential values close to turgor loss were never measured in spite of the high summer temperatures. Very low water potential values $(-2.5 \mathrm{MPa})$ on 27 July for the R2, suggested that many plants had exceeded the turgor loss point. As a consequence, an increase in mortality was observed. However, most of the plants had recovered $24 \mathrm{~h}$ after watering. For Cedrus atlantica and Pinus nigra, a drop of $\Psi$ pd below -3.0 and $-2.5 \mathrm{MPa}$, respectively, reduces the possibility of surviving and if -4.5 and $-3.0 \mathrm{MPa}$ are reached, recovery is impossible [21].

Under water shortage conditions (R2), differences between provenances, water supply treatments as well as between dates were obvious. Water stress cycles led to changes in water relation parameters of plant tissues. This is in agreement with other studies of several conifer species $[1,4,13,35,36,38,40,41,42,43]$. The decrease of $\Psi \pi 100, \Psi \pi 0, \varepsilon \max$ and TW/DW, parallel to the increase of $\Delta \Psi \pi$, indicate the development of strategies of acclimation to water stress conditions. However, the response of $\varepsilon$ max cannot be generalised since it is possible to find plants, resistant or hardened to dryness, with higher $\varepsilon$ values [35]; therefore, $\varepsilon$ performance depends on the species [13]. As water stress abates from July to September, water relation parameters tend to recover to values linked with periods of active growth. Such reversible changes have been described for other conifers $[4,32,43]$.

When comparing the reaction of the provenances to water stress, changes in $\Psi \pi 100$ and $\Psi \pi 0$ suggest a more rapid response in the Arenas and Oria provenances. Lower $\Psi \pi 100$ and $\Psi \pi 0$ values would indicate a greater ability to absorb water to maintain turgor when plant water potential decreases.

At the beginning of the season symplastic water content of leaves is almost twofold their dry weight and this ratio decreases during July, as leaves mature and dry matter increases. It is also possible that in water-stressed plants symplastic volume diminishes as cellular integrity is lost and the permeability of the membranes is reduced $[4,32]$. A modification of this pattern was shown by Joly and Zaerr [20] for several populations of Pseudotsuga menziesii (Mirb) Franco under water stress: in spite of the decrease in the ratio of symplastic water to dry weight, the $\Psi \pi 100$, RWC 0 and TW/DW values were not modified by water supply or stress intensity and no differences between populations were found. 
In the growth chamber, a change in $\Psi \pi 100, \Psi \pi 0$ and $\Delta \Psi \pi$ was the first response (days 1 to 32 ) to water stress. Observed also in Pseudotsuga menziesii [20], this acts as a stimulus to induce internal changes in water allocation and elasticity of tissues, which were then noted later (days 32 to 80). Water stress induced an increase of symplastic water content, the opposite response to that observed for the $\mathrm{R} 2$ water supply regime at the nursery. It can be assumed that in the growth chamber plants did not support such high stress and the loss in integrity of membranes was not approached. In spite of the differences previously mentioned, the three provenances showed a similar pattern for the water relation parameters, and their genetic potential for water stress acclimation may be limited by growth conditions. Because of the low level of radiation in the growth chamber, osmotic adjustment is affected $[29,41]$.

The results should be interpreted with some caution, since the response of the parameters under study depends on the season, cultural conditions, seed origin and species $[4,27,31,41,42]$ and even on the nature of the tissue sampled from the plant [38]. Colombo [6], in his work with Picea mariana, obtained similar or opposite results to those of other authors, and he suggested some reasons to justify the lack of a uniform pattern for $\varepsilon$. Furthermore, although water deficit induces changes in water parameters, seasonal changes have been found in well-watered plants [14]. On the other hand, differences between populations do exist but they are so small that genetic correlations are difficult to demonstrate [42].

Under moderate water stress, plants will produce as much dry matter (growth) as additional water they would be able to remove from the soil. This ability may be linked to low values of cellular elasticity [29], as occurred in plants in the growth chamber. Under severe water stress, another possibility is that maintenance of tissue water content would be more important than maintenance of water potential. Then, the increase in cell elasticity could be the mechanism for stress acclimation if other mechanisms are limited [25]. This appeared to have occurred to plants under the R2 water supply at the nursery.

In conclusion, the following can be emphasised: $i$ ) With adequate water supply, differences for most of the water relations parameters among provenances are not significant. ii) Restriction of water supply through stress cycles causes noticeable changes in water parameters. A drop in $\Psi \pi 100, \Psi \pi 0$ (osmotic adjustment), $\varepsilon$ max and TW/DW points to acclimatisation strategies by plants to water stress. Differences between Oria and Arenas de San Pedro (provenances from hotter sites) and San Leonardo and the Landes (provenances from colder sites) point to a better or a faster response by the first two provenances to water stress. In addition, the lower specific lealf area of the Oria and Arenas provenances may be a strategy to save water. The Arenas provenance stands out because of its growth, whereas the Landes families lost the potential of biomass production they showed under high water availability. These results are in agreement with the field performance at five and eighteen years old of the same provenances at five experimental plots [2]; therefore, they indicate some validity to the use of water parameters as criteria applied for early selection to 1-year-old $P$. pinaster seedlings.

Acknowledgements: We thank Irena Trnkova Farre] for verifying the English version of this text. This research was supported by CEC- DG 12 Forest Project Contract MA2B-CT91-0040 and the 'Ministerio de Educación y Ciencia' of Spain.

\section{REFERENCES}

[1] Abrams M.D., Comparative water relations of three sticcessional hardwood species in Central Wisconsin, Tree Physiol. 4 (1988) 263-273.

[2] Alía R., Gil L., Pardos J.A., Performance of 43 Pimus pinaster Ait. provenances on 5 locations in Central Spain, Silvae Genel. 44 (1995) 75-81.

[3] Allué J.L.. Atlas Fitoclimático de España, Instituto Nacional de Investigaciones Agrarias, MAPA, Madrid, 1990.

[4] Anderson P.D., Helms J.A., Tissue water relations of Pinus ponderosa and Arctostaphylos patula exposed to various levels of soil moisture depletion, Can. J. For. Res. 24 (1994) 1495-1502.

[5] Bradford K.J., Hsiao T.C., Physiological responses to moderate water stress, in: Lange O.L., Nobel P.S., Osmond C.B., Ziegler H. (Eds.), Encyclopedia of Plant Physiology, New Series, Vol. 12B, Springer-Verlag, Berlin, 1982, pp. $263-324$.

[6] Colombo S.J., Changes in osmotic potential, cell elasticity, and turgor relationships of 2nd-year black spruce container seedlings. Can. J. For. Res. 17 ( 1987 ) 365-369.

[7] Cregg B.M.. Seed-source variation in water relations, gas exchange, and needle morphology of mature ponderosa pine trees, Can. J. For. Res. 23 (1993) 749-755.

[8] Dewald L., White T.L., Duryea M.L.. Growth and phenology of seedling of four contrasting slash pine families in ten nitrogen regimes, Tree Physiol. 11 (1992) 255-269.

[9] Fernández M., Comportamiento de procedencias de Pinus pinaster Ait. con vistas a la selección precoz por su resistencia a la sequía, tesis Doctoral, ETSI de Montes, Madrid, Spain, 1996.

[10] Gil L., Gordo J., Alía R., Pardos J.A., Pinus pinaster Aiton en el paisaje vegctal de la Península Ibérica, Ecología, Fuera de Serie ${ }^{\circ} 1$ (1990) 469-495.

[11] Greenwood M.S., Volkaert H.A.. Morphophysiological traits as markers for the early selection of conifer genetic familiess, Can. J. For. Res. 22 (1992) 1001-1008. 
[12] Grieu P., Guehl J.H., Aussenac G., The effects of soil and atmospheric drought on photosynthesis and stomatal control of gas exchange in three coniferous species, Physiol. Plant. 73 (1988) 97-104.

[13] Grossnickle S.C., Planting stress in newly planted jack pine and white spruce. 2. Changes in tissue water potential components, Tree Physiol. 4 (1988) 85-97.

[14] Grossnickle S.C., Shoot phenology and water relations of Picea glauca, Can. J. For. Res. 19 (1989) 1287-1290.

[15] Grossnickle S.C., Blake T.J., Water relations and morphological development of bare-root jack pine and white spruce seedlings: seedling establishment on a boreal cut-over site, For. Ecol. Manage. 18 (1987) 299-318.

[16] Guehl J.M., Picon C., Aussenac G., Gross P., Interactive effects of elevated $\mathrm{CO}_{2}$ and soil drought on growth and transpiration efficiency and its determinants in two European forest tree species, Tree Physiol. 14 (1994) 707-724.

[17] Higging S.S., Black R.A., Radamaker G.K., Bidlake W.R., Gas exchange characteristics and water relations of Larix occidentalis, Can. J. For. Res. 17 (1987) 1364-1370.

[18] Hopkins E.R., Butcher T.B., Provenance comparisons of Pinus pinaster Ait. in Western Australia, CALMScience 1 (1) (1993) 55-105.

[19] Jiang I., Early testing in forest tree breeding: a review, For. Tree Improv. 20 (1987) 45-78.

[20] Joly R.J., Zaerr J.B., Alteration of cell-wall water content and elasticity in Douglas-fir during periods of water deficit, Plant Physiol. 83 (1987) 418-422.

[21] Kaushal P., Aussenac G., Transplanting shock in Corsican pine and Cedar of Atlas seedlings: internal water deficits, growth and root regeneration, For. Ecol. Manage. 27 (1989) 29-40.

[22] Koide R.T., Robichaux R.H., Morse S.R., Smith C.M., Plant water status, hydraulic resistance and capacitance, in: Pearcy R.W., Ehleringer J.R., Mooney H.A., Rundel P.W. (Eds.), Plant Physiological, Chapman and Hall, London, UK, 1989, pp. 161-184.

[23] Kramer P.J., Boyer J.S., Water Relations of Plants and Soils, Academic Press, Inc., New York, 1995.

[24] Kubiske M.E., Abrams M.D., Rehydration effects on pressure-volume relationships in four temperate woody species: variability with site, time of season and drought conditions, Oecologia 85 (1991) 537-542.

[25] Kwon K.W., Pallardy S.G., Temporal changes in tissue water relations of seedlings of Quercus acutissima, $Q$. alba and Q. stellata subjected to chronic water stress, Can. J. For. Res. 19 (1989) 622-626.

[26] Loustau D., Granier A., Environmental control of water flux through maritime pine (Pinus pinaster Ait.), in: Borghetti M., Grace J., Raschi A. (Eds.), Water Transport in Plants Under Climatic Stress, Cambridge University Press, Cambridge, 1993, pp. 205-218.

[27] Loustau D., Crepeau S., Guye M.G., Sartore M., Saur E., Growth and water relations of three geographically separate origins of maritime pine (Pinus pinaster) under saline conditions, Tree Physiol. 15 (1995) 569-576.
[28] Montero de Burgos J.L., González Rebollar J.L., Diagramas Bioclimáticos, ICONA, Madrid, 1983.

[29] Morgan J.M., Osmorregulation and water stress in higher plants, Ann. Rev. Plant. Physiol. 35 ( 1984) 299-319.

[30] Nguyen A., Lamant A., Variation in growth and osmotic regulations of roots of water stressed maritime pine (Pinus pinaster Ait.), Tree Physiol. 5 (1989) 123-133.

[31] Parker W.C., Pallardy S.G., Leaf and root osmotic adjustment in drought-stressed Quercus alba, Q. macrocarpa and $Q$. stelata seedlings, Can. J. For. Res. 18 (1988) 1-5.

[32] Parker W.C., Pallardy S.G., Hinckley T.M., Teskey R.O., Seasonal changes in tissue water relations of three woody species of the Quercus-carya forest type, Ecology 63 (1982) 1259-1267.

[33] Pereira J.S., Chaves M.M., Plant water deficits in Mediterranean ecosystems, in: Smith J.A.C., Grifficths H. (Eds.), Water Deficits: Plant Responses From Cell to Community, BIOS Scientific Publishers, Oxford UK, 1993, pp. 237-251.

[34] Ritchie G.A., Hinckley T.M., The pressure chamber as an instrument for ecological research. Adv. Ecol. Res. 9 (1975) 165-254.

[35] Ritchie G.A., Shula R.G., Seasonal changes of tissuewater relations in shoot and root systems of Douglas-fir seedlings, For. Sci. 30 (1984) 539-548.

[36] Robichaux R.H., Variation in the tissue water relations of two sympatric Hawaïan Dubatia species and their natural hybrid, Oecologia 65 (1984) 75-81.

[37] Sarrauste N., Photosynthèse, respiration et répartition de matière sèche des jeunes plants de pin maritime (Pinus pinaster Ait.) appartenant à sept provenances et conduits selon deux traitements hydriques, DEA, Université Paris VII, Paris, France, 1982.

[38] Schulte P.J., Henry L.T., Pressure-volume analysis of tissue water relations parameters for individual fascicles of loblolly pine (Pinus taeda L.), Tree Physiol. 10 (1992) 381-389.

[39] Tschaplinski T.J., Norby R.J., Wullschleger S.D., Responses of loblolly pine seedlings to elevated $\mathrm{CO}_{2}$ and fluctuating water supply, Tree Physiol. 13 (1993) 283-296.

[40] Tyree M.T., Jarvis P.G., Water in tissues and cells, in: Lange O.L., Nobel P.S., Osmond C.B., Zeigler H. (Eds.), Encyclopedia of Plant Physiology, New Series, Vol. 12B, Springer-Verlag, Berlin, 1982, pp. 35-77.

[41] Vance N.C., Zaerr J.B., Influence of drought stress and irradiance on plant water relations and structural constituents in needles of Pinus ponderosa seedlings, Tree Physiol. 8 (1991) 175-184.

[42] Zine El Abidine A., Bernier P.Y., Plamondon A.P., Water relation parameters of lowland and upland black spruce: seasonal variations and ecotypic differences, Can. J. For. Res. 24 (1994) 587-593.

[43] Zwiazek J.J., Blake T.J., Effects of preconditioning on subsequent water relations stomatal sensitivity and photosynthesis in osmotically stressed black spruce, Can. J. Bot. 67 (1989) 2240-2244. 